\title{
Adaptability and suitability of local cattle breeds in Egypt: Farmers and actors' perceptions and practices of the cattle value chain
}

\author{
Mona A. Osman ${ }^{1}$ Véronique Alary ${ }^{2,3^{*}}$ Mustafa Khali1 $^{1}$ \\ Ahmed Elbeltagy ${ }^{1}$ Jean-François Tourrand ${ }^{4}$ \\ Charles-Henri Moulin ${ }^{5}$
}

\section{Keywords}

Baladi cattle, land race, farming system, adaptation, climate change, Egypt

Submitted: 22 June 2016

Accepted: 5 January 2017

Published: 30 January 2017

\begin{abstract}
Summary
Egypt, where the mean temperature is expected to increase by $1-1.5^{\circ} \mathrm{C}$ over the next two decades, is particularly concerned with climate change in the Mediterranean. Most of the research works on adaptive animal traits have focused on sheep and goats in non-irrigated areas, with little interest in livestock systems in irrigated areas. However, meat and dairy products in Egypt are mainly supplied by large ruminants - cattle and buffaloes. In addition, research on genetic improvement to increase production has neglected local cattle breeds such as the Baladi, which appears to be endangered. Based on individual and collective interviews conducted in two governorates of Egypt, this study aimed to describe the situation of this local breed based on the perceptions and practices of the actors in the sector (including farmers, traders and service suppliers), and to draw perspectives for its future. From the interviews, the Baladi appeared adapted and more resistant to harsh conditions, especially to extreme warm temperatures, feed shortage periods, and some diseases, in particular foot-and-mouth disease. However, there is no organization or collective action to preserve or promote this breed because of its low level of dairy production, although its meat is highly valued in rural areas and could be the source of a potential niche market.
\end{abstract}

How to quote this article: Osman M.A., Alary V., Khalil M., Elbeltagy A., Tourrand J.-F., Moulin C.-H 2016. Adaptability and suitability of local cattle breeds in Egypt: Farmers and actors' perceptions and practices of the cattle value chain. Rev. Elev. Med. Vet. Pays Trop., 69 (3): 95-103

\section{INTRODUCTION}

The Intergovernmental Panel on Climate Change (IPCC) report confirmed the level of warming, especially in South Mediterranean countries (van Oldenborgh et al., 2013). To face the major expected effects of climate change, and particularly the temperature increase in South Mediterranean countries, a renewed interest for the question of

\footnotetext{
1. Animal Production Research Institute / Agricultural Research Centre, Dokki, Cairo, Egypt

2. CIRAD, UMR Selmet, 34398 Montpellier, France.

3. ICARDA, Rabat, Morocco.

4. CIRAD, UPR Green, 34398 Montpellier, France.

5. Institut national d'études supérieures agronomiques, Montpellier, France.

* Corresponding author

Tel.: +212 6540722 48; email: veronique.alary@cirad.fr
}

preservation of local breeds has emerged. These local breeds have the reputation of being more resistant to extreme conditions and might play an important role in the adaptation response to climate change (FAO, 2011). In this line, in different Mediterranean environments, farmers have developed for a long time production systems adapted to the variability of the resource availability along the seasons and to their own objectives (milk, meat, manure), taking advantage of the adaptive traits of local breeds (Flori et al., 2015). However, this has mainly concerned rain-fed environment. In irrigated systems, management practices developed during the last decades and oriented toward animal performances through exotic breeds have to be modified in order to include other parameters associated with environmental changes, especially temperature increase (Mirkena et al., 2010). The use of animal genetic resources in relation to system management diversity in contrasted environmental situations should allow the identification of the most adapted genotypes and management practices capable of coping with environmental challenges linked to climate change (Anya and Ayuk, 2011). 
Egypt, where the temperature would increase by $1-1.5^{\circ} \mathrm{C}$ over the next two decades (van Oldenborgh et al., 2013), is particularly concerned with this global challenge. Faced with this impending change, many national and international researchers have already pointed out the high importance of adaptive traits, such as body reserves management, disease and heat resistance, feed and water scarcity tolerance related to resource scarce environments and the need to preserve the genetic diversity (Anya and Ayuk, 2011; Flori et al., 2015; Mirkena et al., 2010). However, the majority of these researchers have focused on sheep and goat systems in rain-fed areas with little interest in cattle systems in irrigated areas, despite the fact that large ruminants, i.e. cattle and buffaloes, are much more important than sheep and goat with regard to supplying the population with milk and meat. If droughts have low impacts on feed availability for farmers in irrigated areas where rainfall average levels do not exceed $100 \mathrm{~mm} /$ year, global warming will have significant effects on the sanitary environment and animal performances (FAO, 2011). Moreover, in Egypt research on genetic improvement through crossbreeding programs to increase cattle potential has neglected local breeds, such as the Baladi, which has even become threatened by extinction (Galal, 2012).

Within the framework of the Genetic Adaptation of Bovine Livestock and Production Systems in the Mediterranean Region (GALIMED) project regarding the adaptive genetics of cattle and the productive systems in the Mediterranean area (Laloé, 2014), it was proposed to understand how the adaptation of local breeds is perceived and managed by farmers in Mediterranean countries. Based on individual and collective interviews conducted in two governorates of Egypt, this study aimed to describe the perceptions and practices related to the Baladi native breed, at farm and local levels. The objective was to understand why local breeds were neglected, especially with regard to their adaptability to a warming environment, in order to draw perspectives for the future of the breed. The perceptions were analyzed in terms of adaptation to an uncertain environment at local level and in terms of suitability to farming systems at family farm level.

In Egypt, the earliest evidence of cattle that can be considered as a local breed dates back to $8000 \mathrm{BC}$ in the Fayum and pertains to the species Bos aegyptiacus. It is now recognized as a subspecies of Bos taurus in the scientific taxon of domestic cattle. If different local strains are observed according to the locality (Joshi et al., 1957), the conformation of the indigenous cows appears to be very similar. The main traits are: i) a medium size and long body, ii) a lean musculature and light bones; iii) short horns perpendicular to the line of profile; iv) ears of medium size carried horizontally; and v) a coat color which varies from yellowish-brown to red. The generic term of all local strains of indigenous domestic animals is Baladi (Figure 1). The word Baladi refers to all native cattle populations making no distinction among them (different strains). There has been no serious effort to characterize the Baladi into different breeds (Galal, 2007).

Egypt has known a rapid growth in the number of lactating buffaloes and cows over the last 60 years, reaching around 1,893,500 buffaloes and 1,735,600 cows in 2010 (Ministry of Agriculture and Land Reclamation). However, if the lactating females ( $>2$ years of age) of exotic or crossed breeds have registered a spectacular growth with a positive rate of variation of $40 \%$ and $210 \%$, respectively, between 1961 and 2010 , the Baladi cows registered a decrease of around $6 \%$ over that period. Moreover, their average contribution to milk supply did not exceed 17\% over the period 2000-2006 (Galal, 2012). This decrease in the number of Baladi females and their proportional contribution to the national herd could be alarming from the point of view of maintaining biodiversity and sustaining a valuable genetic resource, but also in terms of adaptation to future climate conditions.

Adaptive capacity is generally defined as the ability to survive, grow and reproduce despite variations that occur in a defined environment
(Mirkena et al., 2010; Barker, 2009). Adaptation abilities include adaptation to heat stress (thermotolerance), nutritional stresses (less feeding than required, ability to reduce metabolism or to mobilize fat reserves) and resistance to parasites and diseases (Mirkena et al., 2010). These abilities are referred as adaptability. They mainly rely on functional traits such as reproductive, metabolic, neurological, immunological traits and hair coat characteristics (Berman, 2011). In this study, we determined the adaptive traits perceived by local stakeholders which can be equally relevant to give perspectives on the use of these local breeds in the future.

However, these criteria of adaptability are mainly oriented toward facing global changes with little consideration for the suitability of the local breed to current farming systems and farmers' strategies. Suitability refers to the ability of the local breed to fit farm constraints and farmers' strategies. We propose to analyze the two sets of criteria related to adaptability and suitability, and examine how the local breed can become a relevant resource for future farming systems.

\section{MATERIALS AND METHODS}

\section{Study sites}

Considering that neither a breed association nor a herd book for localcow breeds exist, the sampling procedure was based on the geographic distribution criterion and on expert knowledge of extension services (agricultural technicians, veterinarians) or traders. Two research sites in the western delta were selected. The first site was located in the governorate of Beheira, on the border of the New Reclaimed Lands in the west delta and the second site in the governorate of Menoufeya, in the old cultivated lands, where the rates of urban pressure and land fragmentation are among the highest in Egypt (Figure 2).

These two locations enabled us to address the different roles of the Baladi in the farming systems as draft animals in potato cultivation (Beheira) or meat production (Menoufeya). In order to have diversified information on Baladi cattle, we collected data at two levels: i) farm level with a questionnaire focusing on the farming system and the suitability of the local strain; and ii) local level, using an expert questionnaire focusing on collective perceptions regarding the adaptive traits of this local strain.

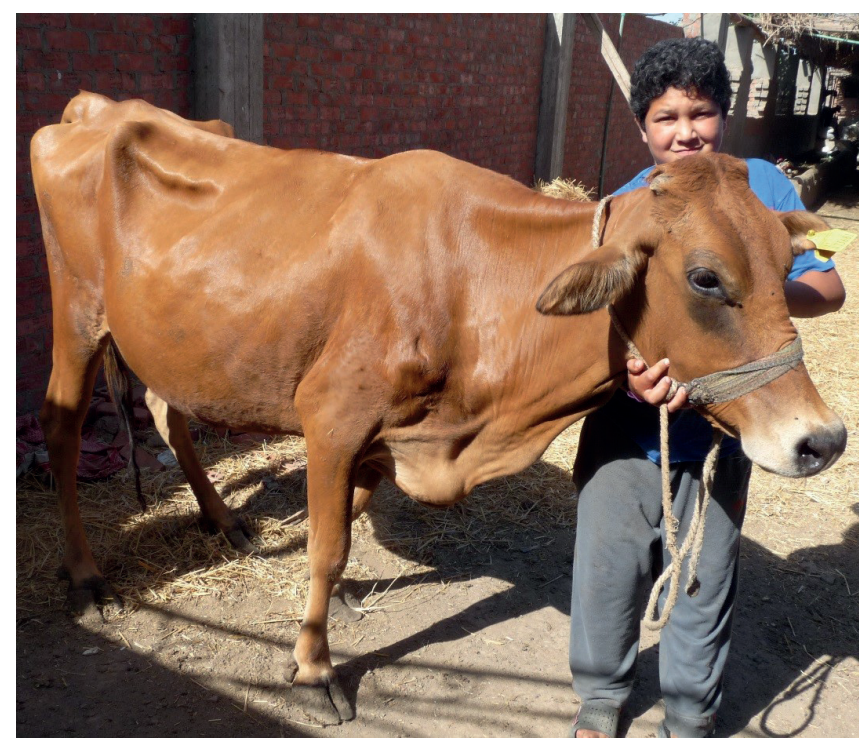

Figure 1: The Baladi local breed in Beheira governorate, Egypt. (C) V. Alary, 2013) 


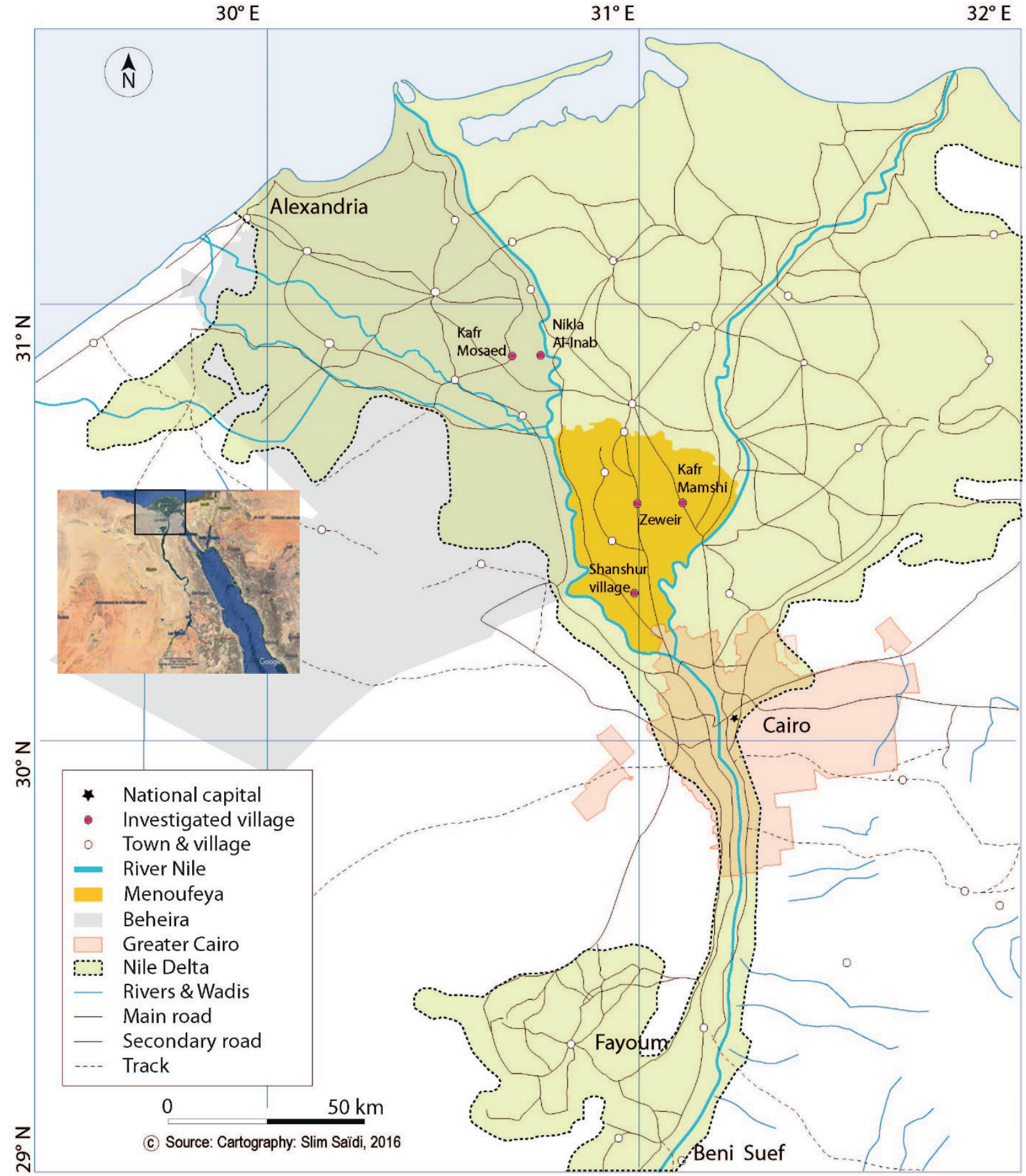

Figure 2: The two studied sites in the western delta of Egypt (Source of the satellite photo: Google Earth).

\section{Method and sample for the expert questionnaire}

We organized two stakeholder meetings: the first one in Itay, in $\mathrm{Al}$ Barud district in Beheira governorate in the local office of the development agency, and the second one in Ashmun district in Menoufeya governorate in the meeting room of the livestock association (Figure 2). Twenty-three local stakeholders participated: 14 in Beheira and 9 in Menoufeya. The majority of participants were breeders involved in local agricultural associations (Table I). The sample also included representatives of local agricultural associations, feed traders, one milk trader in Beheira and one veterinarian in Menoufeya.

We used a semi-structured questionnaire that aimed to understand the place of the Baladi strain in the local supply chains in terms of economic contribution, social perception and preferences. It comprised two parts: i) the general description of the breeds and the farming systems in which the local breed is used at local level, the diversity of the rearing systems and their dynamics, and the identification of the criteria of adaptability; and ii) the description of the collective actions, services and institutions involved in breed management.

The meeting was organized in three steps. Firstly, the research team presented the project. It was followed by an open discussion on the roles of Baladi cows in the farming systems, the market chain, and some of the advantages and disadvantages of this local strain were pointed out. One expert questionnaire was filled based on this collective discussion. Secondly, the participants were divided into subgroups to discuss one by one each part of the questionnaire. After the 


\section{Table I}

Number of stakeholders in the meetings in the two studied areas in the western delta of Egypt

Stakeholders

Association manager

Breeder

Concentrate trader

Milk trader

Veterinary

Total

\section{Beheira}

\section{Menoufeya}

Total

group discussion, each stakeholder filled in one questionnaire according to his own point of view. At the end, the coordinator of each group summarized the discussion of his group and a general discussion generated more details on the different points raised. Shifting back and forth between collective and individual interviews allowed taking into consideration all points of view, especially that of the small breeders who were less comfortable in the collective discussion.

\section{Method and sample for the farm questionnaire}

The farm questionnaire was aimed at understanding the advantages and disadvantages of Baladi cows in comparison to other genetic resources (crossbreeds and breeds like Holstein Friesian cows) in the whole farming system, as well as the long-term perspective of the breed at farm level. The questionnaire was structured in four parts (Lauvie et al., 2013): i) trace the history of the local breed in the farm; ii) understand the local breeding system by describing the land and crop system, and the livestock and feed systems in relation with the objectives of the farmer and his family (mainly marketing orientations); iii) explore the viewpoint of farmers regarding the suitability of the local breed in comparison with other breeds; and iv) discuss the collective actions (already existing or which could be designed) around the preservation of the local breed.

The management practices of the Baladi and their performances were approached through a set of qualitative questions about feeding systems, housing, veterinarian care, animal performances and marketing connections of animal products, compared to crossbreds (mainly Baladi crossed with Holstein or Friesian) or buffaloes. The objective was to characterize and understand the livestock system using the local breed. The approach of the suitability of the Baladi strain was based on open-ended questions where farmers expressed their own criteria of suitability and their perception on the advantages/disadvantages of the Baladi regarding these criteria.

The sample comprised ten farmers in the village of Nikla Al-Inabin in Beheira governorate, and seven farmers in the villages of Kafr Mamshi and Zeweir in Menoufeya. It was based on a snowball sampling method (Goodman, 1960) from the contacts provided by the experts involved in the expert questionnaire.

\section{RESULTS}

\section{Dynamics of the Baladi breed at local level}

In the earlier stage of the study, the regional data given by experts revealed a contrasted situation between the two governorates (Table II). In Menoufeya, the majority of the farmers who reared the local breed had only one Baladi, utilizing it for draft work, mainly tillage for potato cultivation; and the rest of the herd was composed of

\section{Table II}

Estimation by the experts of the number of local-breed cattle in the two villages of the collective meetings in the western delta of Egypt

\begin{tabular}{lcc} 
& $\begin{array}{c}\text { Kafr Mosaed } \\
\text { (Beheira } \\
\text { governorate) }\end{array}$ & $\begin{array}{c}\text { Shanshor } \\
\text { (Menoufeya } \\
\text { governorate) }\end{array}$ \\
\hline $\begin{array}{l}\text { Total num. of } \\
\text { Baladi animals } \\
\begin{array}{l}\text { Total num. of } \\
\text { female Baladi cattle }\end{array}\end{array}$ & $575[500-650]$ & 2000 \\
$\begin{array}{l}\text { Num. of farms } \\
\text { with Baladi cattle }\end{array}$ & {$[25-100]$} & {$[1500-2500]$} \\
\hline $\begin{array}{l}\text { Total num. of } \\
\text { cattle stock }\end{array}$ & 3000 & $1000[500-1700]$ \\
\hline
\end{tabular}

crossbreds (mainly Baladi x Friesian). In Beheira, a few farmers had the local breed. The farmers who reared it had on average 6-7 head per herd. The second difference was the geographical distribution of Baladi cattle: a small number of villages had Baladi cattle in Beheira, whereas Baladi cattle were common and covered all the areas of potato cultivation in Menoufeya.

In Menoufeya, the majority of stakeholders observed a decrease in Baladi cattle over the last 10 years, mainly for economic reasons (i.e. low milk performance with around $5 \mathrm{~kg} /$ day vs $5-10 \mathrm{~kg}$ for crossbreds, and low growth rate at 500-600 g/day vs $1000 \mathrm{~g} /$ day for crossbreds). In addition, two of them mentioned some problems related to diseases and mortality. In Beheira, almost half of the stakeholders observed a decrease because of low economic performances for milk and meat, but also because of a feed cost increase that affected all dairy cattle. However, four of them observed an increasing dynamic of the local breed. The main reasons were due to farm preferences: 'they want this breed', 'they prefer this breed' as tradition and with no economic or agronomic reasons. Nevertheless, this trend does not seem to be supported at local or public level. With the exception of some farmers who had mentioned the existence of a data collection system for milk, there was no local association or research development on this local breed. Only two mentioned the general association of Animal Wealth Development that had allegedly undertaken some actions on the local breed but without being able to mention any details.

\section{Farming systems with Baladi cattle}

Based on expert interviews, the herd mixed with the local breed, crossbreds and/or buffaloes were the more frequent livestock systems in both areas. If the majority of crossbreds in Beheira were crossed with Friesian, two third mentioned some crossbreds with Holstein and Brown Swiss in Menoufeya. Only three stakeholders mentioned separate livestock systems for the local breed based on producing young unfattened calves. However, according to them, Baladi cattle were reared because of the tradition inherited from their ancestors. Baladi cattle were mainly used as draft animals or for calf sale, whereas crossbreds chiefly produced milk and meat, and buffaloes served to cover the family consumption of typical dairy products. Based on the farm survey (17 farmers), the herd was made up of 3-4 Baladi cattle with crossbreds and buffaloes in Beheira, whereas in the studied villages of Menoufeya it comprised 1-2 Baladi animals and buffaloes. Only one farmer relied exclusively on Baladi cattle. 
The cultivated areas were larger in the villages of Beheira governorate (on average 4.8 feddan $^{1}$ in Beheira vs 1.4 in Menoufeya). In both areas, the cropping system followed a rotation of two crops per year. The main traditional cropping system was based on wheat and Egyptian clover (called berseem) (Trifolium alexandrinum) and a few vegetables such as potato in the winter and forage or grain maize, rice or various vegetables (e.g. bean, tomato) in the summer. In Beheira, half of the cultivated land was allocated to forage crops (berseem and maize), whereas in Menoufeya, this part increased up to $69 \%$ in the summer, mainly to produce green maize and maize silage. In all of the surveyed farms, the main source of labor was the family (around 2.5-3 family workers) for all agricultural operations and animal husbandry. All farmers in Beheira used occasional workers, whereas in Menoufeya the farmers did not rely on occasional workers because of the small land size. The main agricultural equipment consisted of manual tools such as the hoe, and a cart to transport feeds and crop products from the house to the crop fields or vice versa.

At family level, only one farmer in Beheira had an off-farm job whereas most of the farmers in Menoufeya worked outside the farm (five out of seven interviewed farmers). Two farmers in both governorates reared sheep and goats along with cattle and buffaloes. The high diversity of activities in Menoufeya was directly related to the small size of the land, which did not cover all the family needs (Alary et al., 2015).

\section{Management practices and technical and economic results}

The majority of farmers had their own family house and a small storage room to keep feedstuffs and grains and closed or semi-closed barns for animal housing. Generally, the animals were reared together. However, in Beheira farmers tried to manage different places for fattening, dairy and draft animals, but without any physical barriers. Animals spent the majority of their day in animal housing.

As practiced in the irrigated lands of the Nile Valley, the feeding system was based on green fodder and seasonal crop residues. In winter (from October to April-May), all farmers cultivated green fodder, mainly berseem, for animal feeding and the majority of farmers added wheat straw as crop residues in the dietary rations. In summer, the main forage was green maize (called darawa), plus maize grain and straw. However, a large diversity in feed supplementation was observed between farms. In Beheira, $40 \%$ of the farmers supplemented their animals with concentrate compared to $100 \%$ in Menoufeya. The main concentrates were wheat bran, cottonseed cake or soybean. In addition, most of the farmers $(88 \%)$ made maize silage in the two governorates, using the whole maize plant or the stalk with only $3 \%$ molasses as additives for fermentation. Seven of them who made silage used it all year long, whereas others used silage only in summer (Beheira) and two farmers only in winter (Menoufeya). Hay was not common, mentioned by only two farmers. There was no specific ration between the breeds; only the quantity could vary between crossbreds, buffaloes and local breeds.

The main form of health care was vaccination. The common and systematic vaccine was against foot and mouth and was offered by governmental services. The other vaccines were dependent on the prevalence of the disease in question and probably the experience of each farmer.

Reproductive performances were highly dependent on the farmers' practices. During the mating period, the main practice consisted in daily bringing the females in estrus to neighbors who reared a male. The main criteria for choosing the bull were color and body

1. feddan $=0.42$ hectare conformity, as well as the proximity of the farm with a bull. Only four farmers used artificial insemination. According to farmers, AI presents a number of risks related to the detection of the right period, availability of the inseminator, and the quality of the semen. The average age at first calving for the local breed was around 31 months in Beheira and 25 months in Menoufeya. This gap can be explained by the regular use of supplementation in Menoufeya. The calving intervals were between 12-13 months in Beheira and 12-15 months in Menoufeya [by comparison, crossbreds first calve at 30.7 months of age and have a calving interval of 13.4 months (Hammoud et al., 2010)]. Farmers usually culled their dams when they became weak. The purchase or replacement of heifers was mainly based on the phenotype, then on performance. The animals were kept for replacement based on their good shapes and the reproductive performance of their dams.

The main economic return of the Baladi is meat. Based on the collective interviews, the average estimations of the daily growth rate were respectively $600 \mathrm{~g} /$ day (with a range of 450-750 g/day) in Menoufeya and $320 \mathrm{~g} / \mathrm{day}$ (200-400 g/day) in Beheira. The feeding system appeared to be the main difference. In Menoufeya the majority of farmers sold young females at around 24 months old and with an average weight of $400-450 \mathrm{~kg}$; in Beheira the farmers sold younger calves (around 4 months at $250-300 \mathrm{~kg}$ ) or young bulls. The market price was around EGP 10,000/head in Beheira for an average weight of $370 \mathrm{~kg}$, compared to EGP 14,000/head for an average selling weight of about $430 \mathrm{~kg}$ in Menoufeya. Thus, the average unit live weight price ranged between EGP 26 and 33 per kilogram in 2013-2014. Most of them were satisfied with the selling price of animals, although feed prices had incurred a major increase over the period because of economic problems brought on by political events since the revolution of 2011. In Menoufeya, Baladi meat was a better value for its appreciated taste by a class of consumers looking for less fat content. Despite this preference, there was neither an organization nor a specific place for slaughtering. The majority of the transactions took place at the farms or the local markets. Buyers were mainly traders, and secondarily butchers, consumers or breeders.

The average milk production of Baladi cows was of around 1100 liters over six months (6-7 L/day). Almost $40 \%$ of the milk production was used for home consumption whether for human consumption or suckling calves. In Beheira $60 \%$ of fresh milk was marketed (farm gate price around EGP 2.66/L), whereas in Menoufeya less than 33\% of fresh milk was sold (average price EGP 2.83/L) in 2013-2014. Price differences were due to the proximity of milk traders. However, there was no difference in milk price between the Baladi and crossbreds although Baladi milk contains 4-5\% fat (compared to 3-4\% in crossbreds), and despite the fact that the price of buffalo milk could reach EGP 4-5/L. Only $60 \%$ of farmers in Beheira and $40 \%$ in Menoufeya transformed fresh milk into cheese for the market. Between 20-30\% of farmers in both studied areas sold cheese products at EGP $8 / \mathrm{kg}^{2}$. In both areas $40 \%$ of farmers produced cream and butter, mainly for family consumption. Finally, the Baladi were also used for draft work and produced around $0.25 \mathrm{~m}^{3}$ manure per day. Only one stakeholder mentioned hide enhancement.

We thus estimated the yearly gross income based on these statements (Table III). Using data from the SIADEEP ${ }^{3}$ project, we estimated the same indicators for crossbred herds by respecting the same stage of sale per calf. The table highlights the positive margin of crossbreds compared to the Baladi in the Old Lands (Menoufeya in the delta

2. With an average ratio of eight liters of fresh milk for one kilogram of cheese plus butter and cream for family consumption

3. Research project on the socioeconomic impacts of the implementation of milk collection centers at farm and local levels. It is funded by the Danone Ecosystem Foundation. Implemented in two zones (new and old lands), the farm survey conducted in 2014 allowed us to approach the yearly gross income for crossbreeds. 


\section{Table III}

Estimation of the yearly gross income from a single Baladi cow over its whole career in the two studied areas in the western delta of Egypt, and comparison with crossbreds (1 US\$ = 7 EGP; 2014)

\begin{tabular}{|c|c|c|c|c|}
\hline & \multicolumn{2}{|c|}{ Baladi } & \multicolumn{2}{|c|}{ Crossbreds } \\
\hline & Beheira & Menoufeya & Beheira & BeniSuef \\
\hline \multicolumn{5}{|l|}{ Animal performance } \\
\hline Weight of sold calf (kg) & 275 & 425 & 275 & 425 \\
\hline Age of calf at selling (days & 120 & 720 & 72 & 434 \\
\hline Growth rate (g/day) & 600 & 600 & 1000 & 1000 \\
\hline \multicolumn{5}{|l|}{ Expenses } \\
\hline Concentrate (kg/head/day) & 1.33 & 3.22 & 5.6 & 5.2 \\
\hline Av. price of concentrate (US\$/kg based on maize grain) & 0.31 & 0.31 & 0.31 & 0.31 \\
\hline Total concentrate cost for dam (US\$/head/year) & 75 & 182 & 392 & 364 \\
\hline Total concentrate cost for calf (US\$/growing period) & 50 & 729 & 127 & 708 \\
\hline Area in forage to cover feed requirement (fed./TLU) & 0.46 & 0.64 & 0.61 & 0.63 \\
\hline Cost of produced feed for the dam and its calf & 189 & 261 & 249 & 258 \\
\hline \multicolumn{5}{|l|}{ Revenues } \\
\hline Calf sale (US\$/head) & 1062 & 1977 & 1062 & 1977 \\
\hline Milk products (US\$/head) & 418 & 445 & 671 & 806 \\
\hline Gross income from one Baladi cow (US\$/year) & 1102 & 1015 & 811 & 1186 \\
\hline
\end{tabular}

TLU: tropical livestock unit $(250 \mathrm{~kg} / \mathrm{head}) ; 1$ feddan $=0.42$ ha

and Beni Suef in the Nile Valley, respectively). In fact, lower inputs required for the Baladi than for crossbreds offset the Baladi low performance. In the New Reclaimed Lands, sales of calves at 120 days resulted in a lower profitability of crossbreds than of the Baladi.

This first approach to livestock systems and livestock management practices showed that there was no specific practices related to the local breed. The main difference was the expected animal products: mainly regular yearly calving and draft for the Baladi, and milk and meat for other breeds and species.

\section{Suitability and adaptive traits of local breeds}

\section{Suitability of the local breed}

Figure 3 shows the main indicators of suitability of the Baladi breed in the two governorates according to the farmers' interviews. Three main criteria were common to both areas: 'behavior', 'heat resistant' and 'crop cultivation'. The common criterion was the behavior of the local breed that was qualified as quiet and more manageable than crossbreds. However, we observed major differences for the criteria heat resistant in Menoufeya with regular calving, and crop cultivation in Beheira where potato is an important cash crop. In Beheira, farmers mentioned their preference for Baladi cattle meat and milk products: milk for its high fat percentage compared to crossbreds' milk (keeping in mind that buffalo is less adapted to this harsh environment close to the desert) and meat for its low fat content. We noted that the low feed requirement criterion was more prevalent in Menoufeya than in Beheira, where the land segmentation has drastically limited feed production. These differences underlined the specificities and constraints of both socio-agrosystems.

\section{Adaptive traits}

Figure 4 shows the main adaptive traits of the Baladi breed to its environment according to expert stakeholders. The three main criteria previously mentioned to characterize suitability were again the

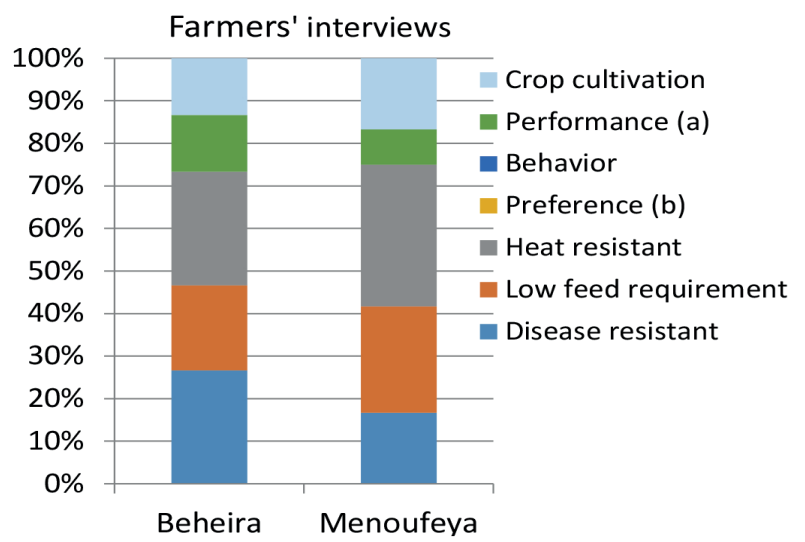

Figure 3: Main criteria of suitability of the Baladi local breed in the two studied sites in the western delta of Egypt (17 farmers). (a) Regularity in calving; (b) Preference of milk and meat.

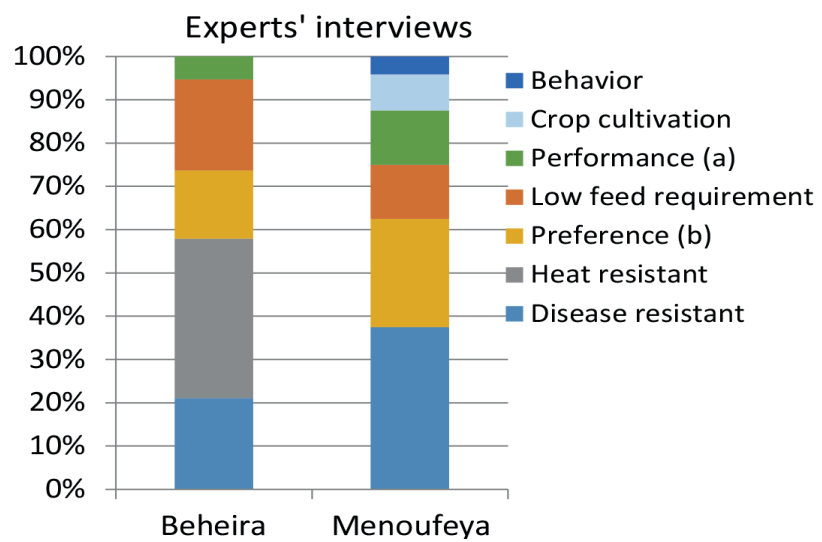

Figure 4: Main adaptive traits of the Baladi local breed in the two studied sites in the western delta of Egypt (23 experts). (a) Calving and calf conformation; (b) Preference of milk and meat. 
most cited: disease resistance, heat resistance and preference of meat and milk products. The farmers were more interested in the behavior of the animals with regard to breeding and draft labor in the cultivation system, whereas experts pointed out the factors of disease and heat resistance in relation to environmental contexts.

We can also notice that the animal performances of the local breed, mainly regular calving and draft use, represented $25 \%$ of the adaptive traits, whereas the stakeholders underlined the meat quality as being highly appreciated locally.

In summary, in Beheira the main reasons for preserving local strains were their heat and disease resistance to their environment, whereas in Menoufeya experts mentioned the market preference was due to the proximity of the demand (rural density and the large city of Menoufeya). The criteria of the breeding system came later on. However, we also observed a high similarity between the criteria of suitability and adaptability in relation with the agro-ecological contexts in both areas.

\section{Advantages and disadvantages of the local breed}

As main advantages, almost half of the farmers, chiefly in Beheira, mentioned the high draft capacity of the Baladi and $24 \%$ of the farmers mentioned its adaptation to a harsh environment. Also in relation with climate change and heat stress, $65 \%$ mentioned regular calving. Based on the general opinions of the farmers and in comparison with crossbreds, all the farmers in Beheira considered the local breed as an advantage in term of breeding. On the other hand, in Menoufeya half of farmers mentioned some disadvantages that were mainly related to animal performance (growth rate or milk yield). The results were opposite for the advantages of the Baladi with regard to marketing: all farmers in Menoufeya recognized their net advantage, whereas only half in Beheira were satisfied and more than three quarters underlined the bad conformation of calves.

As suggested in the experts' interviews, the main disadvantage was the low milk performance even if the taste of Baladi milk was appreciated because of its higher fat content. One of the common uses of Baladi animal products was meat for family consumption, mainly for family or religious sacrifices such as Aïd Al-Adha ${ }^{4}$. The meat marketing system was mainly based on direct sale in Beheira or through traders in Menoufeya to supply a specific market. There was no specific local breeding stock in Menoufeya even if one third of the experts knew breeders who were good suppliers of the local breed.

\section{Future: preservation of the local breed}

None of the interviews mentioned a Baladi cattle association or a recording system to monitor animal performances in Egypt. The only ruminant association was the buffalo breeders' association despite the existence of animal wealth associations or cooperatives with multi-purpose activities in agriculture.

In Menoufeya, the main supports from both public and private institutes were equally distributed between the veterinary units, and animal wealth associations for large ruminants, whose main activity is the supply of feed concentrates, the banks for loans and investments, and the market support. However, three farmers only mentioned physical markets for breeding cattle transactions. There were neither specific facilities for Baladi cattle such as bulls, nor AI centers. Some stakeholders reported some logistic and financial support for AI, milk collection or veterinary care. In Beheira, contrary to Menoufeya, six out of the 11 stakeholders knew about the main market, where around $25 \%$ of breeding cattle were sold. In terms of institutional support, two stakeholders

4. One of the most important celebrations for Muslims during which each family sacrifices one male ruminant animal. In Egypt, the sacrifice often consists in a bovine (calf or bull, sometimes a heifer). mentioned a bull center and an AI center in Cairo. However, all highlighted the isolation of breeders in Beheira where there are no development institutes like the agricultural associations found in old lands.

Regarding breed preservation, collectively four strategies were pointed out: i) market-oriented policy; ii) geographical label (for Menoufeya only); iii) promotion of consumers' awareness; and iv) implementation of subsidies. However only two to three stakeholders (and only breeders) supported these ideas in the experts' interviews. During the farmers' interviews, no one reported collective actions and they did not believe in these collective actions. For the interviewed farmers, the priorities mentioned were the availability of improved sire (three farmers) and improved veterinary care (four farmers). However, the requested improvements concerned all breeds and not only the local breed. For them, the main way to increase the expected benefits of the Baladi would be via feeding improvement (mainly feed values) at low cost, and genetic improvement.

\section{- DISCUSSION}

In terms of adaptive traits, according to the majority of experts' interviews, the Baladi breed was perceived as more resistant to harsh conditions, especially to extreme high temperature, but also more robust with regard to low feed intake (mainly in terms of quality variations), and resistant to diseases, in particularly to FMD. However, we observed variations of priority between experts and farmers. In both areas, all experts highlighted the trait of disease resistance, mainly in relation with the outbreak of FMD in 2013, whereas only farmers from Menoufeya mentioned this trait. This can be explained by the higher rate of the FMD impact in the delta area. Heat resistance ranked as first factor according to experts in Beheira, equally with the behavior criterion according to farmers in Menoufeya. This revealed the different levels of the expected factor impacts. For experts, heat stress stood out in Beheira, which is located at the border of the desert zone, whereas in Menoufeya heat stress is a common factor for the entire delta area. Conversely, farmers in Menoufeya observed different levels of resistance of animal species (mainly the Baladi vs crossbreds) to heat, notably in term of calving. Though these results related to a harsh environment, we also noted that farmers described the adaptive traits mainly according to farm constraints, whereas experts addressed the problem at local or even regional level. Therefore, we can observe different perceptions according to the scale.

The Baladi fills many functions such as supplying farmers and their family members with high quality and typical products (cheese, meat but also leather), draft labor for crop cultivation, contributing to soil fertility management, but also in terms of savings, enhancing crop by-products, and eventually local transportation. This statement confirms previous studies about the suitability of local strains to the agrarian systems (Vissac, 2002) in southern countries (Bourbouze, 1984, in Morocco; Lericollais and Faye, 1994, in Senegal). The common traits of suitability of the local breeds in both areas were the animal behavior with regard breeding and the low feed requirements compared to crossbreds (in term of quantity). In relation to behavior, farmers included the animal character (quiet and manageable, especially for draft labor). They also had a clear preference for the conformation of this local strain. Beyond these advantages, farmers were economically constrained to adopt crossbreds (with Holstein or Friesian) for milk production for either family consumption or market sale, even if Baladi products were highly appreciated (especially, the higher fat content of milk and the low fat content of meat). Profitability was the first constraint in the maintenance of this strain at farm level taking into account the costs of feed production. Moreover, Baladi dairy products are as economically valued as crossbreds' dairy products, without consideration for content. 
This whole situation explains why, today, purebred Baladi cows have become scarce. In addition, this factor of milk productivity supplants the factor of fertility of Baladi cows (due to regular parturition performance). But some studies in North Africa show that local breeds have generally longer careers than crossbreds or imported cattle in developing countries (Sraïri and Baqasse, 2000), mainly because of their resistance to harsh conditions. Finally, cases where Baladi cow milk can be used to feed buffalo calves also occurred because of the high price of buffalo milk, the latter being often reserved for sale or to be processed as butter or cheese. This practice has not been observed in our sample but it is often the case in the farming systems of the Nile Valley.

In parallel, this study confirms the statement that a breed is a cultural rather than a biological or technical entity (Eding, 2008). The discussions with farmers clearly showed their attachment to their local strain even if today farmers are constrained to crosses with exotic breeds mostly for economic reasons. They expressed their attachment through praises on the quality of products (milk and meat) and their animal conformation description. They also regularly referred to tradition. However, the high land segmentation in Egypt compels farmers to privilege economic performance on the short term rather than adaptation on the medium long term. In the New Reclaimed Lands of the west delta (Beheira), farmers can raise more animals and thus maintain local breeds that constitute a security in terms of reproductive performance at whole farm level.

As in many developing countries, there are no collective organizations or actions to preserve or promote this breed even if research studies highlight the adaptive traits of the local strains. The national programs in Egypt but also in North African countries (Sraïri, 2004) have widely given attention to the dairy sector development by designing programs or national projects based on massive imports of exotic cattle breeds. The statement is similar in all countries: shortened careers due to early culling because of diseases, feed insufficiencies, longer calving period due to environmental stress mainly heat stress, etc. Nowadays, with the intensification of climate constraints such as high temperature events and the frequency of drought periods that reduce feed production, these programs based on genetic improvement reveal their limits to develop the sector on the medium and long run. Moreover, they have largely underestimated the consumers' preference, especially that of rural populations for local and typical products. With the growing importance of added-value markets for local and typical products in urban areas, local strains of cattle constitute a potential for labelling, or niche markets.

\section{- CONCLUSION}

The adaptive traits appeared to be insufficient to ensure preservation of Baladi cattle in Egypt. If the study highlighted the main drivers of these dynamics in relation with short-term economic objectives mainly profitability at farm level -, all the stakeholders acknowledged the advantages of local breeds allowing for a better transformation of scarce feed resources produced on small farm areas and their higher resistance to environmental stresses such as heat or disease shocks. However, the promotion of typical animal products could be one potential lever. At national level, these findings raise many questions for policy makers and the society regarding the demographic situation of Baladi cattle, threatened by crossbreeding programs and economic sector development, in terms of biodiversity but also of new promising added-value markets for farmers.

\section{Acknowledgments}

The material presented here was collected within the framework of the research project 'Genetic Adaptation of Bovine Livestock and
Production Systems in the Mediterranean Region' (GALIMED) within AAFCC metaprogram, the French Institute for Agricultural Research (INRA) in association with the International Agricultural Research Center for Development (CIRAD), the International Centre for Agricultural Research in the Dry Areas (ICARDA), and the Egyptian Animal Production Research Institute (APRI). We especially thank all the researchers and technicians from APRI for their participation and support to identify the areas of investigation, and all the breeders and stakeholders interviewed for the time spent with us.

\section{REFERENCES}

Alary V., Aboul-Naga A., El Shafie M., Abdelkrim N., Hamdon H., Metawi H. 2015. Roles of small ruminants in rural livelihood improvement - Comparative analysis in Egypt. Rev. Elev. Med. Vet. Pays Trop., 68 (2-3): 79-85

Anya M.I., Ayuk A.A., 2011. Genetic diversity and climate change: Implications for animal production systems in Africa. Asian J. Agric. Res., 5: 217-222

Barker J.S.F, 2009. Defining fitness in natural and domesticated populations. In: Adaptation and fitness in animal populations: Evolutionary and breeding perspectives on genetic resource management (Eds Van der Werf J., Graser H.-U., Frankham R.). Springer, 3-14

Berman A., 2011. Invited review: are adaptations present to support dairy cattle productivity in warm climates? J. Dairy Sci., 94 (5): 2147-2158

Bourbouze A., 1984. Etude intégrée d'un système agro-pastoral dans le Haut Atlas. Cah. Rech. Dev. (3-4): 19-29

Eding H., 2008. A breed is a breed if enough people say it is. Editorial. Globaldiv Newsl. (4): 1-4

Flori L., Moazami Goudarzi K., Lecomte P., Moulin C.-H., Thévenon M.F., Alary V., Casabianca F., et al., 2015. Adaptation of Mediterranean bovine livestock to climate constraints. Genetic diversity and breeding systems. In: Climate-Smart Agriculture, Global Science Conference, Corum, Montpellier, France, 16-18 March 2015. http://csa2015. cirad.fr/var/csa2015/storage/fckeditor/file/L2\%20Climate-smart\%20 Strategies(1).pdf

Galal S., 2007. Farm animal genetic resources in Egypt: Factsheet. Egypt. I. Anim. Prod., 44: 1-23

Galal S., 2012. Dairy sector in Egypt: past and present development. In: Proc. Training Workshop Interdisciplinary Approach of Urban and Periurban Traditional Dairy Chain (Eds Alary V., Galal S., Tourrand J.-F.), Cairo, Egypt, 10-14 June 2012. www.google.fr/url?sa=t\&rct= $\mathrm{j} \& \mathrm{q}=\&$ esrc $=\mathrm{s} \&$ source $=$ web \& $\mathrm{cd}=1 \& \mathrm{ved}=0$ ahUKEwi5_4e_5snKAh UCyT4KHddFDgoQFgggMAA\&url=http $\% 3$ A $\% 2$ F\% 2 Fumr-selmet. cirad.fr\%2FFichiersComplementaires $\% 2$ Fproceeding_DAIRY_final2. pdf\&usg=AFQjCNGXo2y6yMIVmkMcX-8RVF7Vdrge3A

Goodman L.A., 1960. Snowball sampling. Ann Math. Stat., 32 (1): 148-170. http://projecteuclid.org/DPubS/Repository/1.0/ Disseminate?view=body\&id=pdf_1\&handle=euclid.aoms $/ 1177705148$

Hammoud M.H., El-Zarkouny S.Z., Oudah E.Z.M., 2010. Effect of sire, age at first calving, season and year of calving and parity on reproductive performance of Friesian cows under semiarid conditions in Egypt. Arch. Zootech., 13 (1): 60-82

Joshi N.R., McLaughlin E.A., Phillips R.W., 1957. Types and breeds of African cattle. FAO, Rome, Italy, 397 p. (Agricultural Studies; 37)

Laloe D., 2014. GALIMED Project - Genetic adaptation of bovine livestock and production systems in the Mediterranean region. AAFCC, INRA. www.accaf.inra.fr/en/Actions-and-projects/adaptation_livestock/ GALIMED/\%28key\%29/0

Lauvie A., Rolland C., Moulin C.H., Casabianca F., 2013. How Corsican cattle breeders consider the adaptation of their breed, an exploratory approach. In: Book of abstracts 63rd EAAP Annual Meeting. Wageningen Academic Publishers, Netherlands, p. 216

Lericollais A., Faye A., 1994. Des troupeaux sans pâturages en pays sereer au Sénégal. In : Dynamique des systèmes agraires - à la croisée des parcours : pasteurs, éleveurs, cultivateurs (éds Blanc-Pamard C., Boutrais J.). Orstom, Paris, France, 165-196

Ministry of Agriculture and Land Reclamation, 2010. Consolidated results of Agriculture census 1990 and 2010. MALR, Cairo, Egypt 
Mirkena T., Duguma G., Haile A., Tibbo M., Okeyo A.M., Wurzinger M., Sölkner J., 2010. Genetics of adaptation in domestic farm animals: A review. Livest. Sci., 132: 1-12

Pilling D., Hoffmann I., 2011. Climate change and animal genetic resources for food and agriculture: state of knowledge, risks and opportunities. Rome, Italy, FAO. (Background Study Paper; 53) http:// tinyurl.com/khdcegu

Sraïri M.T., 2004. Typologie des systèmes d'élevage bovin laitier au Maroc en vue d'une analyse de leurs performances. Thèse Doct. Faculté universitaire des Sciences agronomiques, Gembloux, Belgique. https://tel.archives-ouvertes.fr/tel-00423512
Sraïri M.T., Baqasse M., 2000. Evaluation du devenir et des performances de génisses laitières frisonnes importées au Maroc. Livest. Res. Rural Dev. (12) : 3. www.cipav.org.co /lrrd//rrd12/3/sra123.htm

VanOldenborgh G.J., Collins M., Arblaster J., Christensen J.H., Marotzke J., Power S.B., Rummukainen M., Zhou T., 2013. Annex I: Atlas of global and regional climate projections. In: Climate change 2013: the physical science basis. (Eds Stocker T.F., Qin D., Plattner G.-K., Tignor M., Allen S.K., Boschung J., Nauels A., Xia Y., Bex V., Midgley P.M.). IPCC, Cambridge University Press, Cambridge, UK

Vissac B., 2002. Les vaches de la République. Saisons et raisons d'un chercheur citoyen. Paris, France, QUAE, 506 p.

\section{Résumé}

Osman M.A., Alary V., Khalil M., Elbeltagy A., Tourrand J.-F., Moulin C.-H. Adaptabilité et pertinence des races bovines locales en Egypte : perceptions et pratiques des producteurs et des acteurs de la filière bovine

L'Egypte, où la température moyenne augmenterait de 1 à $1,5{ }^{\circ} \mathrm{C}$ au cours des deux prochaines décennies, serait particulièrement exposée au changement climatique dans la zone méditerranéenne. La majorité des travaux de recherche sur les caractères adaptatifs des animaux se sont concentrés sur les ovins et les caprins dans les zones non-irriguées, avec un faible intérêt pour les systèmes d'élevage dans les zones irriguées, alors que les gros ruminants - bovins et buffles assurent l'essentiel de l'apport en lait et viande de I'Egypte. De plus, la recherche sur l'amélioration génétique pour augmenter la production a ignoré les races bovines locales, telle que la Baladi qui semble être en voie de disparition. A partir d'entretiens individuels et collectifs menés dans deux gouvernorats de l'Egypte, la présente étude visait à décrire la situation de la race locale Baladi, à partir des perceptions et pratiques des acteurs de la filière (dont les éleveurs, commerçants et fournisseurs de service), et d'en tirer des perspectives pour son devenir. D'après les entretiens, la Baladi serait adaptée et plus résistante à des conditions difficiles, en particulier aux températures chaudes extrêmes, à des périodes de carence alimentaire, et à certaines maladies, en particulier la fièvre aphteuse. Cependant, il n'y a pas d'organisation ou d'action collective pour préserver ou promouvoir cette race en raison de son faible niveau de production laitière, bien que la viande soit très appréciée dans les zones rurales et pourrait être à I'origine d'un potentiel marché de niche.

Mots-clés : bovin Baladi, race indigène, système d'exploitation agricole, adaptation aux changements climatiques, Egypte

\section{Resumen}

Osman M.A., Alary V., Khalil M., Elbeltagy A., Tourrand J.-F., Moulin C.-H. Adaptabilidad y habilidad de las razas de ganado local en Egipto: percepciones de los finqueros y actores y prácticas de la cadena de valor del ganado

Egipto, donde se espera un aumento de la temperatura media de $1-1.5^{\circ} \mathrm{C}$ durante las próximas dos décadas, se encuentra particularmente concernido con el cambio climático en el Mediterráneo. La mayoría de los trabajos de investigación en los caracteres de adaptabilidad animal se han enfocado en ovejas y cabras en áreas no irrigadas, con poco interés en los sistemas de ganadería en las zonas irrigadas. Sin embargo, los productos de carne y leche en Egipto son principalmente suministrados por grandes rumiantes - ganado y búfalos. Además, la investigación en el mejoramiento genético para aumentar la producción ha obviado razas de ganado local como la Baladi, que parece en peligro de extinción. Basados en entrevistas individuales y colectivas conducidas en dos gobernaciones de Egipto, este estudio pretende describir la situación de esta raza local, basada en las percepciones y prácticas de los actores en el sector (incluyendo finqueros, intermediaros y proveedores de servicios), así como diseñar perspectivas para el futuro. De las entrevistas, la Baladi sería adaptable y más resistente a las condiciones rudas, especialmente a temperaturas extremas, periodos de escasez de alimento y algunas enfermedades, en particular la fiebre aftosa. Sin embargo, no existe una organización o acción colectiva para preservar o promover esta raza, debido a su baja producción láctea, a pesar de que su carne es altamente valorada en zonas rurales y podría ser la fuente de un mercado específico potencial.

Palabras clave: ganado bovino Baladi, raza indígena, sistema de explotación, adaptación al cambio climático, Egipto 
